\title{
The Comparison of Propofol and Ketofol Side Effects During Sedation with Spinal Anesthesia
}

\author{
Spinal Anestezi Sırasında Verilen Sedasyonda Kullanılan Propofol ve Ketofol Yan Etkilerinin \\ Karșılaștırılması
}

\section{Aysu Hayriye Tezcan', Dilșen Hatice Önek², Nurcan Yavuz², Hidayet Ünal², Aysun Nadide Postacı², Hülya Özden Terzi², Mustafa Baydar², Onur Özlü²}

${ }^{1}$ Kafkas Üniversitesi Tip Fakültesi, Anesteziyoloji ve Reanimasyon Anabilim Dal, Kars; ${ }^{2}$ Ankara Numune Eğitim ve Araştırma Hastanesi, Anesteziyoloji ve Reanimasyon Kliniği, Ankara, Türkiye

\begin{abstract}
Aim: Research into ideal sedative agents for patient comfort, cardiopulmonary stability and fast recovery without mental impairments continues. Our primary objectives were to compare haemodynamic parameters, recovery time, emergence reactions, vomiting and satisfaction ratios between groups administered propofol-ketamine or propofol.
\end{abstract}

Material and Method: Sixty-one ASA I-III adult patients undergoing elective orthopaedic lower limb surgery under spinal anaesthesia were studied. The Mini-mental State examination was used preoperatively and post-operatively. Vital signs were recorded preoperatively, during surgery and during recovery. After sensory block was obtained, patients received a $0.4 \mathrm{mg} \mathrm{kg}^{-1}$ propofol loading dose. Pre-surgery, continuous infusions started: Group P, propofol with saline; Group KP, propofol with ketamine in a 3:1 ratio. Postsurgery, in the post-anaesthesia care unit, patients' vital signs were monitored, and side-effects and satisfaction ratios recorded.

Results: The groups did not differ in demographic variables. There was no statistically significant difference in preoperative and postoperative MMT examination scores, systolic blood pressure, mean blood pressure, heart rate, respiratory rate or oxygen saturation between groups $(p>0.05)$. But in group $P$ four patients had deep hypotension and two of them need sedation termination. Mean recovery time of Group KP and Group $P$ was 14 min and 7 min, respectively. No respiratory adverse event was observed. In Group $K P$, four patients vomited. There were no psychomimetic adverse reactions.

Conclusion: It was found that ketamine infusion (ratio 3:1) prolonged recovery time but it is far less important near its haemodynamic benefits. In this combination, propofol may counterbalance psychomimetic effects of ketamine, but not vomiting.

Key words: spinal anaesthesia; sedation; propofol; ketamine

Aysu Hayriye Tezcan, Kafkas Üniversitesi Tip Fakültesi, Sağllk Uygulama Araștırma Hastanesi Kars - Türkiye, Tel.05326735711 Email.aysndr@gmail.com

Geliş Taribi: 19.10.2017 • Kabul Taribi: 03.11.2017
ÖZET

Amaç: Hasta konforu, kardiyopulmoner stabilite ve zihinsel bozukluklar olmaksızın hızlı derlenme için en ideal sedatif ajan seçimi üzerine araștırmalar devam etmektedir. Bu çalıșmadaki hedefimiz, sedasyonda propofol-ketamin veya propofol uygulanan gruplarda hemodinamik parametreleri, derlenme süresi, derlenme komplikasyonları, kusma ve hasta memnuniyet oranları açısından karșılaștırmaktı.

Materyal ve Metot: Spinal anestezi altında elektif ortopedik alt ekstremite cerrahisi planlanan ASA I-III 61 erișkin hasta çalıșmaya alındı. Tüm hastalara preoperatif ve postoperatif Mini-Mental Test uygulandı. Ameliyat öncesi, ameliyat sırasında ve derlenme sırasında vital bulgular kaydedildi. Spinal blok elde edildikten sonra, hastalara $0,4 \mathrm{mg} \mathrm{kg}^{-1}$ propofol yükleme dozu verildi ve takibinde ilaç infüzyonları bașlatıldı (Grup $P$, salin+ propofol; Grup KP, 3:1 oranında ketamin+propofol). Ameliyat sonrası derlenme ünitesinde hastaların vital bulguları, yan etkiler ve memnuniyet oranlar kaydedildi.

Bulgular: Gruplar demografik değișkenlerde farklılık göstermedi. Preoperatif ve postoperatif MMT muayene skorlarında, sistolik kan basıncında, ortalama kan basıncında, kalp atım hızında, solunum sayısı veya oksijen satürasyonunda gruplar arasında istatistikse olarak anlamlı fark yoktu $(p>0,05)$. Ancak Grup P'de dört hastada derin hipotansiyona gözlendi ve ikisinde sedasyon durduruldu. Grup KP ve Grup P'nin ortalama derlenme zamanı sırasıyla 14 ve 7 dakika idi. Hiçbir solunum sistemi yan etkisi gözlenmedi. Grup KP'de dört hasta da kusma gözlendi. Hiçbir psikomimetik advers reaksiyon gelișmedi.

Sonuç: Ketamin infüzyonunun (3:1 oranı) ciddi hemodinamik fayda sağlamasının yanında derlenme süresini uzattığı gözlemlendi. Ayrıca bu doz kombinasyonuyla propofolün ketaminin psikomimetik etkilerini baskılayabildiğini ama kusmayı engelleyemediğini sonucuna varıldı.

Anahtar kelimeler: spinal anestezi; sedasyon; propofol; ketamin 


\section{Introduction}

Regional anaesthesia benefits both patients and anaesthesiologists. For patients, the most important consideration is post-operative comfort ${ }^{1}$ and, for anaesthesiologists, cardiovascular stability and early recovery ${ }^{2}$ take priority. These factors enhance the importance of sedation that ensures patients' comfort, analgesia, anxiolysis and amnesia. It has been shown that tolerance to the regional block is better with sedation, especially during long surgical procedures with uncomfortable positioning such as in orthopaedic surgery ${ }^{3}$. Respiratory depression, haemodynamic instability, uncontrolled movements and vomiting are the potential risks of sedation ${ }^{4}$. Therefore, research into the perfect drug or drug combination for sedation during regional anaesthesia continues. In this study we compare a propofol-ketamine combination with propofol alone as a sedative infusion. The primary objectives are to compare haemodynamic parameters, recovery time, post-operative reactions, vomiting and satisfaction ratios between groups.

\section{Material and Method}

Sixty-one adult patients (ASA physical status I-III) undergoing elective orthopaedic lower limb surgery under spinal anaesthesia were studied. Ethical approval for this study (protocol number: 26247029-514-04-01) was provided by the Ethical Committee of Turkey Pharmaceuticals and Medical Devices Agency, Ankara, Turkey on 06 June 2014. Written informed consent was obtained from all participants. The participants were between 25 and 80 years old, both male and female, and some of them had comorbidities such as hypertension, coronary artery disease and diabetes mellitus. Patients with an allergic reaction to propofol or ketamine; obese patients $\left(\mathrm{BMI} \geq 35 \mathrm{~kg} / \mathrm{m}^{-2}\right)$; patients with uncontrolled hypertension ( $>170 / 100 \mathrm{mmHg}$ ) or clinically significant cardiac, pulmonary, hepatic or renal dysfunction; and patients who had psychiatric disorders, neurological impairment or contraindications for spinal anaesthesia were excluded from participation in this study. Patients were allocated to one of two groups randomly using a sealed, opaque envelope technique. Group P received intravenous propofol + saline infusion, and Group KP received intravenous propofol + ketamine infusion. Infusion protocols are described below and the anaesthesiologist who administered the drugs and observed the patients during surgery was blind to the medication, whether ketamine or saline.
In the preoperative holding area, baseline mental functions were assessed by using the Mini-mental State (MMS) examination ${ }^{5}$. This test assesses the patient's cognitive functions such as attention, calculation, memory, recall and speech. The maximum score in this test is 32 , and those who could not complete the test within 10 min or scored lower than 20 were excluded from the study. The patients did not receive premedication. After MMS examination, an intravenous cannula was inserted for fluid and drug administration. Patients were transferred to the operating room, and non-invasive preoperative baseline measurements of blood pressure, heart rate and oxygen saturation were recorded. Perioperative monitoring also included electrocardiogram and respiratory rate. All vital sign values were recorded at 5 -min intervals during the operation and 10-min intervals in the recovery room. After 500$\mathrm{ml}$ saline infusion to all patients, spinal anaesthesia was performed with a dose of bupivacaine $0.5 \%$ that was sufficient to achieve an adequate sensory block for the proposed surgery. The sensory level was assessed at 3-min intervals using a cold swab until the level was adequate for the surgery. No patients received sedative medications until an adequate sensory level had been obtained for the surgery. All patients received supple-

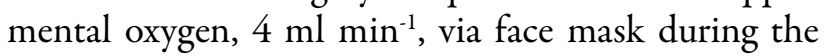
surgery and recovery periods. After an adequate sensory block was obtained, all patients received a $0.4 \mathrm{mg}$ $\mathrm{kg}^{-1}$ propofol loading dose intravenously, then continuous infusions of $2 \%$ propofol + saline or $2 \%$ propofol + ketamine were started simultaneously from two separate infusion pumps before surgery in Group $P$ and Group KP, respectively. For Group KP, one syringe was filled with $45 \mathrm{ml}$ ( $900 \mathrm{mg}$ ) of $2 \%$ propofol and another syringe was filled with $6 \mathrm{ml}(300 \mathrm{mg})$ of ketamine + $39 \mathrm{ml}$ saline. For Group P, one syringe was filled with $45 \mathrm{ml}(900 \mathrm{mg}$ ) of $2 \%$ propofol and another was filled with $45 \mathrm{ml}$ saline. The two drug or saline infusions were combined in the same venous cannula of each patient and the infusion rates were set at same rate. A 3:1 propofol-to-ketamine ratio was maintained. In both groups, propofol infusion rate was started with $25 \mu \mathrm{g}$ $\mathrm{kg}^{-1} \mathrm{~min}^{-1}$ and calibrated according to the sedation level of the patients. The other drug (saline or ketamine) infusion rates were set according to the propofol infusion. Sedation level was assessed using the Ramsey sedation scale 6 and drug infusions regulated to maintain a sedation level of 4-5. A respiratory rate of less than 8 breaths $\min ^{-1}$ or apnoea longer than $15 \mathrm{~s}$ were defined as respiratory depression and treated with bag-mask 
ventilation, and sedative infusions were decreased or stopped. Decreases in oxygen saturation of more than 5 and a $25 \%$ reduction in heart rate from baseline values were recorded. Reductions in mean blood pressure (MBP) of $25 \%$ from baseline or less than $60 \mathrm{mmHg}$ were treated with $5 \mathrm{mg}$ i.v. ephedrine. All other intraoperative side-effects such as involuntary movements, agitation, nausea, vomiting, supplemental medications and fluid requirements were recorded during surgery and the recovery period. Sedation infusions were discontinued at the end of surgery. Total sedative requirements and recovery times were noted. The duration between sedation termination time and patient response time to the verbal command 'open your eyes' was taken as the recovery time. At the completion of surgery, patients were transferred to the post-anaesthesia care unit (PACU), where observation was continued. All vital signs were recorded at 10 -min intervals. Thirty minutes after arrival in the PACU, a second MMT was conducted. Side-effects such as hypotension, bradycardia, desaturation (criteria mentioned above), nausea, vomiting and psychomimetic effects (agitation, nystagmus, double vision, hallucinations) were noted with their treatments. Patients were discharged to the ward when their vital signs stabilized, they were oriented, they had no intractable side-effects and motor function had returned to their lower limbs.

Patient and surgeon satisfaction were evaluated postoperatively on a three-point scale $(1=$ bad, $2=$ borderline $3=$ good).
To detect recovery-time difference, the sample size of 61 carried $81 \%$ statistical power and 0.05 level of significance. Statistical package SPSS 20.0 for Windows (SPSS, Chicago, IL) was used for statistical analysis. All values are expressed as mean \pm standard deviation. Qualitative data were analysed by a chi-square test. Quantitative data were analysed by analysis of variance or the Mann-Whitney $U$-test. The haemodynamic parameters obtained at various time intervals within the same group were compared with the baseline values using the paired $t$-test. As both parameters were normally distributed, the correlation coefficients and their significance were calculated using the Pearson test. A $p$-value of $\leq 0.05$ was deemed significant.

Clinical Trial Registration Number: ACTRN 12615000372583

\section{Results}

The two groups did not differ with respect to age, sex or weight $(p>0.05)$ (Table 1$)$. The dermatomal level of anaesthesia was satisfactory in all patients. Preoperative and post-operative MMT examination scores were not significantly different between groups $(p>0.05)$; and post-operative MMT scores were not lower than preoperative values for both groups. Blood pressure dropped after the spinal anaesthesia, but not to clinically significant levels. There was no statistically significant difference in terms of systolic blood pressure, MBP, heart rate or respiratory rate between groups $(p>0.05)$. In group KP two patients had

Table 1. Demographic and pharmacological variables of the groups

\begin{tabular}{|c|c|c|}
\hline & Group KP $(n=33)$ & Group $P(n=28)$ \\
\hline Gender (m/f) (n) & $10 / 23$ & $9 / 19$ \\
\hline Age (years) (mean $\pm S D$ ) & $61 \pm 15$ & $59 \pm 16$ \\
\hline Weight $(\mathrm{kg})($ mean $\pm \mathrm{SD})$ & $75 \pm 13$ & $79 \pm 13$ \\
\hline Sedation time (min) (mean \pm SD) & $122 \pm 57$ & $96 \pm 39$ \\
\hline Preoperative MMT score (mean \pm SD) & $26 \pm 5$ & $28 \pm 5$ \\
\hline Post-operative MMT score (mean \pm SD) & $25 \pm 7$ & $28 \pm 5$ \\
\hline Recovery time (min) (mean \pm SD) & $14 \pm 15$ & $8 \pm 3$ \\
\hline Propofol dose (mg) (mean \pm SD) & $342 \pm 256$ & $323 \pm 342$ \\
\hline Propofol dose $\left(\mathrm{mg} \mathrm{kg}^{-1}\right)(\mathrm{mean} \pm \mathrm{SD})$ & $4.6 \pm 3.3$ & $4.1 \pm 4.1$ \\
\hline Propofol infusion rate $\left(\mu \mathrm{g} \mathrm{kg}^{-1}\right.$ per min-1) $($ mean $\pm \mathrm{SD})$ & $38.2 \pm 16.9$ & $41.8 \pm 32.0$ \\
\hline Ketamine dose $(\mathrm{mg})($ mean \pm SD) & $113 \pm 85$ & 0 \\
\hline Ketamine dose $\left(\mathrm{mg} \mathrm{kg}^{-1}\right)($ mean \pm SD) & $1.52 \pm 1$ & 0 \\
\hline Ketamine infusion rate $\left(\mu \mathrm{g} \mathrm{kg}^{-1} \mathrm{~min}^{-1}\right)($ mean $\pm \mathrm{SD})$ & $12.6 \pm 5.7$ & 0 \\
\hline
\end{tabular}


hypotension intraoperatively, two patients had hypotension post-operatively and both patients' blood pressures increased rapidly with one dose $5 \mathrm{mg}$ ephedrine administration. However the statistical analysis did not show any difference respect to mean of the blood pressures; in Group P, four patients had intraoperative deep hypotension, which needed more than one dose of ephedrine, and two of them needed propofol infusion termination for a while until MBP returned to the normal values during the surgery time. In Group P, post-operative hypotension was not observed.

Oxygen saturation was slightly higher in Group KP, but not statistically significantly so. Mean fluid consumption was not different between groups.

A constant degree of sedation was maintained with alteration of drug infusions during surgery. Sedation time of Group PK was higher than Group P, just as surgery time $(p<0.05)$. But there was not a statistically significant difference in terms of total propofol dose, or total propofol infusion rate that shown in Table 1 $(p>0.05)$. For all that, mean recovery time of the patients was statistically different between groups. The mean recovery time of Group KP and Group P was $14 \mathrm{~min}(\mathrm{~min} .5 \mathrm{~min}, \mathrm{max} .90 \mathrm{~min})$ and $7 \mathrm{~min}(\mathrm{~min} .3$ min, max. $16 \mathrm{~min}$ ), respectively. In group KP, two extraordinary recovery times were noted ( $40 \mathrm{~min}$ and 90 $\mathrm{min}$ ). If these two extraordinary results were excluded, the mean recovery time in Group KP was $11 \mathrm{~min}(95 \%$ confidence interval 8.8 to 19.6 ), but still significantly longer than Group P ( $95 \%$ confidence interval 6.4 to $8.7)(p<0.05)$. In statistical analysis, the prolongation of recovery time was not correlated with propofol total dose, propofol infusion rate, sedation time or age of the patients $(p>0.05)$. Taking this into account, the difference in recovery time might come from ketamine infusion; but higher ketamine doses were not correlated with longer recovery times. The dose of both propofol and ketamine required to produce the desired level of sedation will vary considerably between individuals. So, a higher ketamine dose is likely to be due to increased individual requirements and such patients are likely to have an equally rapid recovery from sedation. Adverse events during the study are shown in Table 2. There were no respiratory adverse events observed. During the study time, only one patient had nausea in Group P, but without vomiting; but in Group KP one patient had nausea and four patients had vomiting. These patients were treated with $4 \mathrm{mg}$ intravenous ondansetron. In both groups psychomimetic adverse events such as hallucinations, agitation or bad dreams were not observed.

\section{Discussion}

In the present study, we compared two anaesthetic agents (propofol and ketamine) in numerous combinations to find an ideal sedation technique. We looked for orthopaedic surgery patients, who were mostly older patients with multiple comorbidities, and because of the trauma during bone surgery, patients need efficient sedation despite their predicted high risk of complications. While searching for an ideal sedative agent, we maintained the sedation level constant using the Ramsey sedation scale in both groups to compare the adverse events, haemodynamic changes and postoperative neurologic state.

In summary, we found that with a ratio of $3: 1$ ketamine infusion prolonged the recovery time, increased post-operative vomiting incidence and did not improve haemodynamic values significantly. And in this combination ratio propofol may counterbalance psychomimetic effects of ketamine infusion, but not vomiting.

Table 2. Adverse events

\begin{tabular}{lcccc}
\hline & \multicolumn{2}{c}{ Group KP $(\mathrm{n})$} & \multicolumn{2}{c}{ Group P $(\mathrm{n})$} \\
\cline { 2 - 5 } & Intraoperative & Postoperative & Intraoperative & Postoperative \\
\hline Nausea & 0 & 1 & 1 & 0 \\
Vomiting & 1 & 3 & 0 & 0 \\
Bradicardia & 0 & 1 & 0 & 0 \\
Hypotension & 2 & 2 & 4 & 0 \\
Patients requiring ephedrine & 2 & 2 & 4 & 0 \\
Psychomimetic effects & 0 & 0 & 0 & 0 \\
\hline
\end{tabular}


Propofol has many advantages during sedation such as fast induction, fast recovery and easy regulation of sedation level ${ }^{7,8}$. Its anti-emetic property is an another advantage during sedation. ${ }^{9}$ On the other hand, haemodynamic instability ${ }^{10,11}$ and decline in respiratory drive $e^{12,13}$ even with sedative doses, contraindicate propofol as being the best sedative agent. In addition, propofol is not a good analgesic ${ }^{14}$ or amnestic ${ }^{15}$. In anaesthesiology combining drugs with their lower doses is an attractive choice for anaesthesiologists to exclude some side-effects. To exclude the disadvantageous properties of propofol, many studies researched ketamine addition to propofol sedation in different modalities. When it is used alone, we know that ketamine is a rapidly acting agent with a short half-life.

Another advantageous property of the drug is the preservation of ventilatory effort and protection of pharyngeal and laryngeal reflexes ${ }^{16,17}$. Ketamine is a successful bronchodilator ${ }^{18,19}$, which may be important in patients who have respiratory impairments such as asthma. In the present study, although statistically unimportant, Group KP had slightly better blood oxygen saturation $\left(\mathrm{SpO}_{2}\right)$ levels. Several studies on ketamine administration report that ketamine decreases pulmonary pressures, preserves functional residual capacity and tidal volume, and increases oxygenation ${ }^{20,21}$. We did not observe any respiratory complications in either group. We suggest that ketamine may counterbalance the respiratory depression known to be caused by propofol, especially in patients with respiratory diseases. In addition to these desirable respiratory advantages, ketamine may counteract the cardiovascular depression seen with propofol, particularly in combination with a neuraxial block ${ }^{22}$. In normotensive patients it does not change haemodynamic parameters noticeably, but in hypotensive patients ketamine improved heart rate and systolic blood pressure ${ }^{23-25}$. In terms of vasopressor requirements during ketamine infusions, studies have reported varied results such as decreased or unchanged requirements ${ }^{26,27}$. In the present study we infused the drugs using a 3:1 ratio and observed mostly stable and similar haemodynamic profiles in both groups. Neither mean blood pressures nor mean heart rate values differed between groups, similar to findings in recent studies. When we assessed the total perioperative duration, the vasopressor requirements did not change between the groups. However, in the intraoperative period in Group P, two patients needed termination of their infusions because of deep hypotension, and as a result multiple ephedrine doses were administered. Haemodynamic values were slightly better in Group KP, but not statistically significant. We thought that if the study was planned with higher subject numbers, the haemodynamic difference between groups might be statistically significant. Also, the mean fluid loss and fluid requirements were the same in the two groups. The combination ratio of these two drugs and the administration route, such as bolus or infusion, may determine haemodynamic changes, but the results of previous studies are confused. In the present study, we tried to find a combination ratio which might alter vital signs, but not prolong the recovery time. The 3:1 combination ratio with infusion did not have any additional haemodynamic changes, but slightly prolonged recovery times without any psychedelic side-effects in the present study. Ketamine is known as a strong analgesic in subhypnotic doses, and propofol is known a dose-dependent sedative agent, which allows fast recovery. The combination of these two drugs must meet the expectations of a stable haemodynamic profile and successful post-procedural analgesia with minimal adverse reactions. So a combination with a high ketamine ratio, for example 1:1, may be more beneficial in a short procedural sedation rather than long-term sedation infusions, especially in terms of adverse events. Aldonfatto et al. ${ }^{28}$ analysed 728 ketofol procedural sedations with a 1:1 ratio and found the combination effective enough in terms of analgesia, recovery times and satisfaction, with few adverse events. Akin et al. ${ }^{29}$ showed that low-dose ketamine in a cardiac catheterization procedure provided a reduced opioid requirement, with a better haemodynamic profile. Badrinath et al. ${ }^{30}$ contributed the same idea with their study. Subhypnotic doses of ketamine decreased opioid consumption and as a result improved respiratory function $^{30}$. Messenger et al. ${ }^{31}$ demonstrated that ketamine is safer than fentanyl in procedural propofol sedation. In the present study, we did not evaluate analgesic properties of the drugs combination because of adjunct spinal anaesthesia with complete sensory block.

Emergence reactions (agitation, hallucination) and longer recovery times are the important adverse events with ketamine use and these are the most important factors taken into account by some anaesthesiologists, resulting in limited use of the drug. Clinical studies show that benzodiazepines, thiopental or propofol may prevent emergence reactions. ${ }^{32,33}$ The estimated incidence of recovery agitation in adults receiving ketamine has been reported as between $10 \%$ and $20 \%{ }^{34}$. Aldonfatto et al. ${ }^{28}$ have reported that the agitation 
ratio is $1.8 \%$ in bolus ketofol-administered patients. In the present study, we did not observe any psychomimetic side-effects or bad dreams, and we hypothesized that propofol might successfully counterbalance psychomimetic effects of ketamine in a 3:1 ratio. Guit et al. ${ }^{35}$ and Idvall et al. ${ }^{36}$ concur. Badrinath et al. ${ }^{30}$ used an infusion protocol that included four different ketamine doses with a constant propofol dose, but they did not observe significant haemodynamic changes in their patient groups. They did find that emergence reactions, vomiting and discharge times were directly proportional to ketamine dose (max. ratio was $9.4 \mathrm{mg}$ to $2.83 \mathrm{mg}$ ).

We used MMS examination to evaluate the patients' cognitive functions, especially in Group KP, even if emergence reactions did not occur. There was no significant difference between groups in the mean MMS examination scores. All patients reached preoperative MMSE scores $30 \mathrm{~min}$ after surgery except for two. These two patients also had recovery times longer than $30 \mathrm{~min}$, too. Post-operatively MMS scores showed ketamine did not cause any significant cognitive impairments. Frey et al ${ }^{37}$ report the same results as us in terms of MMS scores after ketamine-propofol sedation.

Another problem with ketamine infusion is nausea and vomiting. In the present study there was no difference between the two groups in terms of nausea. Aldonfatto et al. ${ }^{28}$ report that the vomiting ratio was $0.1 \%$ in the study with bolus administration in a $1: 1$ ratio; but in our study we found $12 \%$, which was not related with ketamine dosage. Badrinath et al. ${ }^{30}$ have reported that vomiting increases with higher doses of ketamine. Propofol with its anti-emetic property was not enough to prevent vomiting in the 3:1 combined group. Modern anti-emetic agents such as 5-HT3 receptor blockers may be recommended before ketamine infusion.

The limitation of this study is not to include other groups for different infusion combinations such as 2:1 and 1:1. Also, the differences between ketamine bolus administration and infusion with the same dose might have been observed as in previous studies in the literature.

In sedation with spinal anaesthesia, analgesia is not extremely important when choosing the sedative agent. Our combination infusion produced a high vomiting ratio and longer recovery times with good cognitive function and no psychomimetic adverse reactions. We recommend ketamine via the bolus route for its analgesic and amnestic properties in short procedural sedations adjunct to propofol infusion to reduce opioid consumption. Vomiting frequency may decrease with this route. We know that spinal anaesthesia often produces cardiovascular instability with a drop in blood pressure due to sympathetic blockade causing peripheral vasodilation and negative inotropy at higher levels. This is then compounded by the use of of propofol for sedation with some patients showing marked drops in blood pressure. This population of elderly patients often have coexisting cardiovascular disease and do not tolerate a fall in blood pressure. In the present study, just as mentioned above, four patients in propofol group had deep hypotension and two of them; both was 80 years old, needed sedation termination and multiple ephedrine administrations for blood pressure recovery. But we did not observe any significant haemodynamic alterations in combined group.

In conclusion, ketamine may alter the recovery time when combined with propofol, but its beneficial effect maintaining cardiovascular stability is more important.

\section{References}

1. De Andres J, Valia JC, Bolinches R. Predictors of patient satisfaction with regional anesthesia. RegAnesth 1995;20(6):498-505.

2. Asehnoune K, Albaladejo P, Smail N, Heriche C, Sitban P, Gueneron JP, et al. Information and anaesthesia: what does the patient? Ann Fr Anesth Reanim 2000;19(8):577-81.

3. Kinirons BP, Bouaziz H, Paqueron X. Sedation with sufentanil and midazolam decreases pain in patients undergoing upper limb surgery under multiple nerve block. AnesthAnalg 2000;90:1118-21.

4. Höhener D, Blumenthal S, Borgeat. Sedation and regional anaesthesia in the adult patient. Br J Anaesth 2008;100(1):8-16.

5. Folstein MF, Folstein SE, McHugh PR. 'Mini-Mental State": a practical method for grading the cognitive state of patients for the clinician. J Psychiatr Res 1975;12(3):189-98.

6. Ramsey MAE, Savege TM, Simpson BR, Goodwin R. With controlled sedation alphaxalone-alphadolone. $\mathrm{Br}$ Med J 1974;22(2):656-9.

7. Schnider TW, Minto CF, Shafer SL, Gambus PL, Andresan $\mathrm{C}$, Goodale DB, et al. The influence of age on propofol pharmacodynamics. Anaesthesiology 1999;90(6):1502-16.

8. Wilson E, David A, MacKenzie N, Grant IS. Sedation during spinal anesthesia: comparison of propofol and midazolam. Br J Anaesth 1990;64(1):48-52. 
9. Borgeat A, Wilder-Smith OH, Saiah M, Rifat K. Subhypnotic doses of propofol possess direct antiemetic properties. AnesthAnalg 1992;74(4):539-41.

10. Mingus ML, Monk TG, Gold MI, Jenkins W, Roland C. Remifentanil versus propofol as adjuncts to regional anesthesia. J ClinAnesth 1998;10(1):46-53.

11. Lauwers MH, Vanlersberghe C, Camu F. Comparison of remifentanil and propofol infusions for sedation during regional ansthesia. RegAnesth Pain Med 1998;23:64-70.

12. Blouin RT, Seifert HA, Babenco HD, Conard PF, Gross JB. Propofol depresses the hypoxic ventilatory respons during conscious sedation and isohypercapnia. Anaesthesiology 1993;79(6):1177-82.

13. Nieuwenhuijs D, Sarton E, Teppema L, Dahan A. Propofol for monitored anaesthesia care: implications on hypoxic contol of cardiorespiratory responses. Anaesthesiology 2000;92(1):46-54.

14. Servin FS, Raeder JC, Merle Jc, Reite K, Marty J, Lauwers MH, et al. Remifentanil sedation compared with propofol during regional anesthesia. ActaAnaesthesiolScand 2002;46(3):309-15.

15. Holas A, Krafft P, Marcovic M, Et al. Remifentanil, propofol or both for concious sedation during eye surgery under regional anesthesia. Eur J Anaesth 1999;16:741-48.

16. Frizelle HP, Duranteau J, Samii K. A comparison of propofol with a propofol-ketamine combination for sedation during spinal anesthesia. AnesthAnalg 1997;84(6):1318-22.

17. Miller AC, Jamin CT, Elamin EM. Continuous intravenous infusion of ketamine for maintenance sedation. Minerva Anestesiol 2011;77(8):812-20.

18. Petrillo TM, Fortenberry JD, Linzer Jf, Simon HK. Emergency department use of ketamine in pediatric status asthmaticus. J Asthma 2001;38(8):357-64.

19. Lau TT, Zed PJ. Does ketamine have a role in managing severe exacerbation of asthma in adults? Pharmacotherapy 2001;21:1100-6.

20. Tokics L, Strandberg A, Brismar B, Lundquist H, Hedenstierna G. Computarized tomography of the chest and gas exchange measurements during ketamine anaesthesia. ActaAnaesthScand 1987;31(89):384-92.

21. Youssef-Ahmed MZ, Silver P, Nimkoff L. Continuous infusion of ketamine in mechanically ventilated children wtih refractory bronchospasm. Intensive Care Med 1996;22:972-6.

22. Hedenstierna G. Pulmonary perfusion during anesthesia and mechanical ventilation. Minerva Anesthesiol 2005;71(1):319-24.

23. Park Gr, Manara AR, Mendel L, Bateman PE. Ketamine infusion. Its use as a sedative, inotrope and bronchodilator in a critically ill patient. Anaesthesia 1987;42(9):980-3.

24. Williams GD, Philip BM, Chu LF, Boltz MG, Kamra K, Terwey $\mathrm{H}$, et al. Ketamine does not increase pulmonary vascular resistance in children with pulmonary hypertension undergoing sevoflurane anesthesia and spontaneous ventilation. AnesthAnalg 2007;105(6):1578-84.
25. Hijazi Y, Bodonian C, Bolon M, Salord F, Baulieu R. Pharmacokinetics and haemodynamics of ketamine in intensive care patients with brain or spinal cord injury. $\mathrm{Br} \mathrm{J}$ Anaesth 2003;90(2):155-60.

26. Kolenda H, Gremmelt A, Rading S, Braun U, Markakis E. Ketamine for analgosedative therapy in intensive care treatment of head-injured patients. ActaNeurochir (Wien) 1996;138(10):1193-9.

27. Tobias JD, Martin LD, Wetzel RC. Ketamine by continuous infusion for sedation in the pediatric intensive care unit. Crit Care Med 1990;18(8):819-21.

28. Andolfatto G, Willman E. A prospective case series of singlesyringe ketamine-propofol (ketofol) for emergency department procedural sedation and analgesia in adults. Academic Emergency Medicine 2011;18(3):237-45.

29. Akin A, Esmaoglu A, Guler G. Propofol and propofol-ketamine in pediatric patients undergoing cardiac catheterization. Pediatric Cardiology 2005;26:553-7.

30. Badrinath S, Syhmala B, Avramov M, Witt TR, Ivankovich AD. The use of ketamine-propofol combination during monitored anesthesia care. AnesthAnalg 2000;90(4):858-62.

31. Messenger DW, Murray HE, Dungey PE, Van Vlyman J, Sivilotti ML. Subdissociative-dose ketamine versus fentanyl for analgesia during propofol sedation: a randomized clinical trial. Academic Emergency Medicine 2008;15(10):877-86.

32. Craven R. Ketamine. Anaesthesia 2007;62:48-53.

33. Erden IA, Pamuk AG, Akinci SB, Koseoglu A, Aypar U. Comparison of two ketamine-propofol dosing regimens for sedation during interventional radiology procedures. Minerva Anesthesiol 2010;76:260-5.

34. Strayer RJ, Nelson LS. Adverse events associated with ketamine for procedural sedation in adults. Am J Emerg Med 2008;26(9):985-1028.

35. Guit JBM, Koning HM, Coster ML, Niemeijer RP, Machie DP. Ketamine as analgesic for total intravenous anaesthesia with propofol. Anaesthesia 1990;46(1):24-7.

36. Idvall J, Ahlgren I, Aronson KF, Stenberg P. Ketamine infusions: pharmacokinetics and clinical effects. Br J Anaesth 1979;51(12):1167-72.

37. Frey K, Sukhani R, Pawlowsky J, Pappas AL, Nikat-Stevens M. Propofol versus propofol-ketamine sedation for retrobulbar nerve block: comparison of sedation quality, intraocular pressure changes, and recovery profiles. AnesthAnalg 1999;89(2):317-21. 